\title{
АНТРОПОЛОГІЧНИЙ ВИМІР КОРЕЛЯТУ БОЛЮ У РОМАНІ ОЛЕСЯ УЛЬЯНЕНКА «ДОФІН САТАНИ»
}

\author{
Фелікс ШТЕЙНБУК
}

\author{
доктор філологічних наук, професор, \\ кафедра русистики та східноєвропейських студій, \\ Університет Коменського у Братиславі, \\ площа Шафарика 6, 814 99, Братислава, Словаччина, \\ feliks.shteinbuk@uniba.sk \\ https://orcid.org/0000-0002-4852-815X
}

DOI 10.25128/2304-1222.20.51.01

\begin{abstract}
In modern Ukrainian literature, in Oles Ulianenko's works in particular, the literary analysis of the texts full of violence and cruelty has become very topical. Hence, taking one of the most complicated and controversial novels "Satan's Dauphin" by Oles Ulianenko, the aim of the article is to suggest an effective and justified variant of methodology to interpret such seemingly "cruel" literary works. The corresponding methodology is based on and determined by the corporal correlate of pain. Owing to this approach, the analytics of Oles Ulianenko's "Satan's Dauphin" based on the corporal correlate of pain has allowed on the one hand to controvert both social-historical and mystical-religious interpretations, and on the other hand to represent an alternative and more credible version of the novel plot under study, where the characters' behavior and actions are caused by their corporal ability to fell pain impulses, which in its turn prove not only emotional-esthetic persuasiveness of the images, which appear due to the writer's artistic strategy, but also determine their anthropological rather than animal character.
\end{abstract}

Key words: Oles Ulianenko, anthropological character, corporality, violence, cruelty, pain correlate.

У сучасній українській літературі загалом і у творчості Олеся Ульяненка зокрема неабиякої ваги набула проблема аналізу художніх текстів, сповнених насиллям та жорстокістю. А тому мета статті полягає у тому, аби на прикладі одного із найскладніших та найсуперечливіших романів Олеся Ульяненка «Дофін Сатани» запропонувати ефективний та обгрунтований варіант методології розгляду подібних, себто «жорстких», творів. У зв'язку із цим основу відповідної методології було визначено через такий тілесний корелят, як корелят болю. Завдяки цьому аналітика роману Олеся Ульяненка «Дофін Сатани», грунтована на тілесному кореляті болю, дозволила, з одного боку, заперечити як суспільно-історичну, так і містично-релігійну інтерпретації, а, з іншого боку, репрезентувати альтернативну, але разом з тим вірогідну версію щодо розуміння змісту розглянутого твору, у якому поведінка і вчинки персонажів зумовлюються їхньою тілесною здатністю до переживання болісних імпульсів, що не тільки засвідчують емоційно-естетичну переконливість посталих внаслідок застосування окресленої художньої стратегії образів, а й визначають їхній аж ніяк не тваринний, а, навпаки, власне антропологічний вимір.

Ключові слова: Олесь Ульяненко, антропологічний вимір, тілесність, насилля, жорстокість, корелят болю.

We współczesnej literaturze ukraińskiej w ogóle oraz w twórczości Olesa Uljanenki problem analizy tekstów literackich pełnych przemocy i okrucieństwa zyskał niezwykłą wagę. Dlatego celem artykułu jest przedstawienie skutecznej i ugruntowanej wersji metodologii rozpatrywania takich, tj. «twardych», tekstów na przykładzie jednej z najbardziej złożonych i kontrowersyjnych powieści Olesa Uljanenki «Księcia Szatana». W związku z tą podstawą określono odpowiednią metodologię za pomocą takiego cielesnego korelatu, jakim jest korelat bólu. W związku z tym analityka powieści Olesa Uljanenki «Księcia Szatana», opartej na cielesnym korelatie bólu, pozwoliła z jednej strony zaprzeczyć interpretacjom zarówno społeczno-historycznym, jak i mistyczno-religijnym, a z drugiej strony zaproponować alternatywnu, ale jednocześnie wiarygodnu wersju rozumienia treści tekstu, w którym o zachowaniu i działaniu bohaterów decyduje ich fizyczna zdolność do przeżywania bolesnych impulsów, ponieważ nie tylko świadczą o emocjonalnej i estetycznej perswazji obrazów, ale także determinują ich nie zwierzęcy, ale przeciwnie, rzeczywisty wymiar antropologiczny.

Slowa kluczowe: Oles Uljanenko, wymiar antropologiczny, cielesność, przemoc, okrucieństwo, korelat bólu.

В одній зі своїх статей польська дослідниця А. Горнятко-Шумілович поставила питання руба про те, що, мовляв, «чи не кожен літературознавець, критик, врешті пересічний 5 Studia methodologica, ISSN 2304-1222, No. 51. 2020 
читач, [який] заглиблюється у тексти Ульяненка, вирішує базове питання, навіщо отаке борсання в морі крові» [Horniatko-Szumiłowicz 2015: 197]. Адже, як зауважує ця авторка, «емоційна реакція читачів на зображені автором жахливості найчастіше дуже різка, шокова, що може призвести до відторгнення того типу прози, їі цілковитого заперечення» [там же: 198].

Окреслена ситуація ускладнюється ще й остільки, оскільки, на думку О. Солов’я, «письменник нічого уже не додасть до свого доробку, [хоч] на увагу до себе - він, як мінімум, заслуговував ще за життя, а сьогодні - і поготів» [Соловей 2013: 261].

Проте, ця увага навіть за умови нейтрально-позитивної настанови вимагає чіткого і недвозначного обгрунтування того, з чим все ж таки усі у різний спосіб причетні до творів Олеся Ульяненка мають справу: зі збоченою «чорнухою» чи зі своєрідним літературноестетичним феноменом?!

Відтак мета пропонованої статті якраз і полягає у тому, аби на прикладі одного із найскладніших та найсуперечливіших романів Олеся Ульяненка «Дофін Сатани» запропонувати ефективний та обгрунтований варіант методології розгляду подібних, себто «жорстких», творів.

Отже, Н. Тендітна в одному з розділів своєї дисертації, означивши цей підрозділ як «Містична мотивація історії маніяка в романі „Дофін Сатани”», наполягає та потусторонній мотивації зображуваних подій загалом та центрального персонажу зокрема, а також на тому, що у цьому творі «сюжет поклоніння ідолу деструктивності повністю перемісти[в]ся в містичну площину» [тут і далі цит. за Тендітна 2009].

I хоча важко, звісно, заперечити той факт, що «у „Дофіні Сатани”, як і в більшості романів О. Ульяненка, багато розмов про Бога, релігію, церкву, Біблію», та чи це автоматично означає, що «злочинний сюжет органічно переходить у містичну площину», про що буцімто свідчить факт, за яким «персонаж О. Ульяненка зустрічається 3 ангелом смерті і веде 3 ним містичні діалоги», внаслідок чого «Білозуб усвідомлює себе об’єктом потойбічних сил, їхнім знаряддям у боротьбі з соціальною несправедливістю»?!

Своєю чергою, і О. Пуніна у шкіці, присвяченому розгляду роману «Дофін Сатани», крім певних цікавих зауваг, наприклад, стосовно ольфакторного чинника, теж, на жаль, припустилася декількох прикрих натяжок або, сказати б, перебільшень. Так, на ії думку, «О. Ульяненко < ..> витворює образ персонажа Івана Білозуба, який дослуховується до чужих голосів посланця сатани, при цьому уникає благих голосів, що намагаються відвернути від скоєння зла $<\ldots>$ і тому стає інструментом цього світового зла на землі, спрямованого проти життя* » [Пуніна 2016: 134-135].

\footnotetext{
* Збережено стилістичні, синтаксичні та орфографічні особливості авторського тексту. 6 Studia methodologica, ISSN 2304-1222, No. 51. 2020
} 
Таким чином, позначаючи маніяка-убивцю «інструментом світового зла», авторка науково-популярного видання, по-перше, вторує Н. Тендітній, яка теж вважає образ маніяка «знаряддям потойбічних сил», по-друге, утверджує разом з колегою існування і сатани, i «світового зла на землі», по-третє, фактично виправдовує холоднокровного та непогамованого злочинця і, нарешті, учетверте, натякає на те, що Білозуб був не одним таким «інструментом», «спрямованим проти життя», - до останніх слід тоді зарахувати і «головного слідчого на прізвище Бондаренко», з вини якого стратили Комету, і фотографа Зісельмана, і водія, і страшно сказати - такого правильного капітана Ракшу. Адже всі вони були мовчазними посіпаками капітана Бондаренка і, звісно, генерала Васьковича тому, що не стали втручатися i погодилися віддати на поталу цього бідолашного сина «шулявської шльондри i конголезійського негра-марксиста, якого убили на „кругловій” дорозі, коли той намагався затягнути до ліжка дівчину ватажка місцевої банди» [тут і далі цит. за Ульяненко].

Але навіть за таких кричущо-ганебних обставин, коли смерть Комети стукає у серце кожній нормальній людині, стверджувати, що цей персонаж «почувається як „страшний звір Апокаліпсису”, тобто має передчуття „страшного суду” над злими силами», і що «до того ж помітна чітка паралель із постаттю Ісуса Христа» [Пуніна 2016: 140] - це, як здається, вже навіть не перебільшення, а радше профанація - і «страшного звіра Апокаліпсису», і постаті Христа, й поготів образу Комети.

Проте наостанок неможливо не згадати ще один висновок з приводу роману «,Дофін Сатани”, у якому за допомогою потворного у вигляді нарочитої експресивної натуральності, створеної передовсім ольфакторним конструктом, О. Ульяненку вдається естетично осмислити „мерзотний Всесвіт” [за М. Уельбеком] сучасності, який людина здатна перебороти, знайшовши шлях до Бога як Духу» [Пуніна 2016: 143].

Отож є роман Олеся Ульяненка «Дофін Сатани», у якому, з одного боку, головний герой у нелюдський спосіб знущається зі своїх нещасних жертв та невблаганно вбиває їх, а 3 іншого - існує бажання зрозуміти, про що тут йдеться і цьому персонажу, і письменнику. I за умови застосування божественної, так би мовити, аргументації усі ці питання вирішуються не надто вибагливо, а втім надзвичайно легко, хоч і вкрай суперечливо та непереконливо, бо ані Білозуб, ані навіть Ракша протягом роману йшли аж ніяк не до Бога, а, щонайбільше, назустріч один одному.

Натомість у протилежному разі, якщо все це розглядати як справи суто людські, а до того ж позбавлені будь-якого містичного підгрунтя, то такий підхід буде, звісно, набагато складнішим, втім все ж таки більш обгрунтованим.

Зокрема, О. Пуніна на початку свого шкіцу, присвяченого «Дофіну Сатани», зазначила, що основу твору становить «неприйняття навколишнього світу» [Пуніна 2016: 125-126]. Цій тезі вторує і А. Горнятко-Шумілович, яка вважає, що «джерела жорстокої прози великого 
Ульяна слід шукати, подібно як у випадку російської „чорнушної прози”, в суспільнополітичних перемінах післягорбачовських часів», оскільки, на думку дослідниці, «молоді прозаїки, у тому числі Ульяненко < .. > намагалися по-новому показати трагізм дедалі більше розчарованого українського суспільства, його поступову деградацію, досліджувати граничні стани скалічених душ» [Horniatko-Szumiłowicz 2015: 190].

Немає сумніву у тому, що суспільно-історичне тло, на якому формувався письменник і на якому поставали його твори, знайшло своє відображення й у романах митця. Але навряд чи можна стверджувати, що це внаслідок «неприйняття навколишнього світу» і «поступової деградації» українського суспільства Іван Білозуб не просто у стані нападу люті несподівано для себе самого вбиває якусь випадкову людину, а перетворює вбивство на довготривалу, багатосерійну містерію - містерію, яка визначає сенс його існування.

Своєю чергою, необхідно зазначити, що загальний пошуковий рух, спрямований на дослідження внутрішніх, а отже, тілесних чинників, тим більше у творах такого штибу, який демонструє роман Олеся Ульяненка, видаються доволі перспективними. Але ефективність розгляду цих тілесних корелятів суттєво залежить все ж таки від їхнього кшталту, що має стосуватися не якихось хоч і важливих, проте локальних, наприклад, ольфакторних аспектів, а, навпаки, виявів тілесності всеохопної і тотальної.

Отож найбільш адекватним і до жанру роману, написаного формально як «крутий» детектив, і до його різновиду, тобто соціально-детективного жанру, i, врешті-решт, до «жорстокого» змісту цього твору є, такий, безумовно, тілесний корелят, як корелят болю.

Зокрема, на думку авторки дисертації з прикметною назвою «Філософія болю» [див. Хайдарова 2003] Г. Хайдарової, «на відміну від багатьох інших переживань (заздрості, скорботи, радості та ін.), біль є неминучим для всіх. Адже біль не зумовлений часом, на відміну від старості, смерті, і не залежить, як хвороба, від стану організму» [Хайдарова MEDIUM].

Таким чином, «біль дається кожному як первісний досвід, а тому має об’єднуючий усі живі істоти характер», через що, на думку цієї філософині, біль може бути визначений як «онтологічна передумова існування» [там же].

3 твердженнями Г. Хайдарової перегукуються і роздуми німецької дослідниці Х. Мейєр, яка переконливо довела, що «художній образ болю завжди виконує інтегруючу функцію, оскільки виражає одне через друге, а тому є усі підстави для того, аби розглядати цей образ як позитивний жест, який здатен призвести до звільнення» [цит. за Хайдарова Боль III],

Вторує наведеній вище думці і німецький психіатр Г. Кранц, який також вважає, що «біль є інтегруючим складником нашого „Я”, якому [складнику] ми інколи завдячуємо усвідомлення цього „Я”» [цит. за Хайдарова Боль II]. 
Це означає, що якщо навіть біль і не «може бути першопричиною, через яку однозначно запускається причинно-наслідковий ланцюжок» [там же], то все одно, на думку тієї ж таки Г. Хайдарової, «зустріч з болем - це зустріч із самим собою поза простором і часом» [Хайдарова Феномен; більш докл. про корелят болю див. Штейнбук 2014: 22-37].

I в усіх артикульованих сенсах текст роману Олеся Ульяненка становить більш, ніж ілюстративний взірець чи взірцевий зразок того, як біль, від якого потерпають практично усі основні персонажі твору, утворює центральний стрижень, що у суттєвий спосіб детермінує розвиток сюжету і всіх тих трагічних колізій, з яких складається зміст книги.

Так, від болю цілком очікувано потерпає Ракша. Однак не тільки тоді, коли він чи не маніакально занурюється у виснажливі пошуки Білозуба i, повертаючись знесиленим додому, відчуває, як «юдольне запустіння виклика[є] думки про намарність людського існування». А це, своєю чергою, «асоцію[єть]ся у нього з незрозумілим, пекучим болем [тут і далі курсив мій. - Ф.Ш.], що ганя[є його] містом від дому до дому» і що засвідчує його внутрішнє переконання, за яким «він < ..> знав, що так необхідно», а тому «вороття назад немає», поки злочинець продовжує залишати за собою кривавий слід.

Натомість полковник Ракша ще й вдається до філософсько-онтологічних, а навіть пафосно-патріотичних рефлексій стосовно кореляту болю, бо, як виявляється, цей персонаж «давно почав розрізняти біль від людського щастя», дійшовши висновку про те, що «отой біль і є людське щастя» і що, попри факт, за яким він «останні роки <..> ходи[ть] навзирці зі смертю», йому «прийдеться покласти перед ногами жінки весь біль, всю любов, всю жагу цього народу, до якого він належав, що його несправедливо кривдили скільки століть».

Звісно, інші персонажі, поза Іваном Білозубом, до такого рівня пафосу не доходять, але від цього їхня причетність до переживання болю аж ніяк не стає менш доткливою. Зокрема, це стосується і матері Білозуба Марії, яка вже на порозі смерті все одно відчувала, що «сморід, задуха, біль - для неї прикра тимчасовість, наче несвоєчасна зупинка трамваю посеред пустирища старого кварталу».

Це так само прогнозовано має стосунок і до Комети, який «між пиятиками < .. > багато читав, з болем спостерігаючи за старіючою матір'ю, що пускалася берега далі і далі, розуміючи, що нічого не може вдіяти, як не зупинити вітер, бо тут править той і влада у нього зовсім інша, коротка і жорстока».

Не уникнули прикрих переживань і зовсім другорядні персонажі. Серед останніх необхідно вказати і на коханця Білозуба на прізвисько Річчі, який через те, що «Іван не з'являвся тиждень», «занудьгував. У нього пропав апетит < ..> I < ..> Розширеними від болю зіницями Річчі подивився на світ».

Слід згадати у цьому контексті і коханця Ліліт, який «утік від неї. Не витримавши розбещеної краси, майже ренесансової вроди, лякаючись витонченого, але непрагматичного, 
чоловічого розуму», і який «навіть закричав на вікна, коли Ліліт, заливаючись слізьми, дивилася у спину, а він розвернувся перекошеним болем і люттю обличчям, швидко, похамськи інтелігентно захаркався: „Гермафродитка хєрова!!! Кому ти тут потрібна?!”».

А також складно оминути увагою та потрібно разом із Ракшею «пригада[ти] обличчя Бондаренка, що ніколи у житті, скільки він його знав, не проймалося ані сумом, ані відразою, але тоді», коли міліціянти опинилися на місті першого злочину вбивці-маніяка, «видно було, як нелюдський біль, що прийшов наче іззовні, заставив сльозитися його [Бондаренка] безвиразні очі, а страх пересмикував німе, як маска, обличчя».

Втім парадокс полягає у тому, що тотальність зображеного у романі болю розповсюджується і на того, хто є його безпосереднім фундатором та продуцентом, тобто на Івана Білозуба.

Виникає навіть враження, за яким найбільше від болю, крім, звісно, жертв, потерпає са́ме нелюд. Адже можна сказати, що його життя починається, власне, з відчуття болю, тому що одним з перших спогадів з його дитинства був спогад про хворобу і смерть матері, «коли Марію ще не привезли з трупарні», а «Іван з кутка спостерігав за людьми в чорному» та «почув удари дзвонів і зіскулився від болю, наче хто усмалив по яйцях, а до вуха доносилося не що інше, як хто спалював велетенські коробки сірників: з’явилося обличчя, - так собі просто зависло серед золотої маяти осені, і нахабно наказало, щоб він їх усіх повбивав. Іван не мав нічого проти, але був надто малим, проте все навколишнє викликало у нього відразу». Втім «коли пика зникла, Івану боляче різало в пахвині і викручувало нирки».

Разом $з$ тим і сюжетна історія Білозуба теж починається з відчуття болю, що виник «наприкінці тижня, коли гуркіт доріс максимальних частот, затряс могутніми ударами децибелів, вибиваючи 3 його голови <..> найдорожчі і найсокровенніші думки». I тільки завдяки тому, що «до нього підступився Ангел < .. > Все перестало боліти, як заніміло».

Біль, крім цього, не тільки супроводжує історію Білозуба, а й у суттєвий спосіб іiі i зумовлює, оскільки «його біль, його лють», наприклад, передують першому злочину і до того ж ніби оздоблюють цей епізод у той момент, коли «погляд [вбивці] натрапив на тоненьку чорну книжечку, яка була нічим іншим, як баптистською Біблією», i «його як хто стусонув у живіт, в саме сонячне сплетіння, розкидавши тріщини болю всим тілом, що спліталися в один вузол, викручуючи зуби».

Так само болем певною мірою завершується чи, точніше, рокується на загал завершення й історії маніяка, який перед тим, як потрапити до рук полковника Ракші i перетворитися на цілковиту нікчему, під час побачення з Ліліт, «розімлівшись, сидів за столиком, самотній, маленький», але при цьому «упивався своєю силою, як упивалася своєю вродою Ліліт», і мріяв про те, як «вона буде його жінкою. Навіть сьогодні», і «він перестане убивати». I «вони поїдуть далеко <..> А непорозуміння зітре час. Це в його силі. Але щось 
буркало і тривожило його <..> непокоїло його, турбувало, як хто бив легко, але боляче у тім'я».

А ще Білозуб подібно до Ракші рефлексує з приводу болю і у якийсь момент «він напросто, колупаючись в зубах, з переляком, радісним та невгамовним, як у квітні місяці, зрозумів, що оті виступки, опуклості, дірочки в зубах, свеблячка болю, а не сам біль, не що інше, як саме його найдовше, найстрашніше, найнужденніше, найпрекрасніше його життя, i воно, оте копирсання, складає невід'ємну частину, воно складає розуміння, життєвий шлях і наснагу».

Зрештою, «він уперто, з насолодою приймав біль, як щось те, від чого може вилікуватися», і болем Білозуб виправдовував також свою кровожерність, вдавшись подекуди до короткої та агресивної дискусії із філософом, якого маніяк зустрів у парку, і ствердивши, що «на то він і мертвий, щоб навік утішитися». Бо, на думку Івана, «мертвому немає сорому, ані болю, ані страху... кошмарних снів».

Таким чином, якщо узагальнити наведені вище рації та приклади, то можна дійти декількох цілком обгрунтованих висновків.

По-перше, той факт, що у випадку із корелятом болю у романі Олеся Ульяненка «Дофін Сатани» йдеться переважно не про фізичний біль, засвідчує коректність інтерпретації цього кореляту як елементу художнього дискурсу. Тим більше що, на думку німецького філософа Д. Кампера, біль розглядається передусім як можливість залишатися живим, як потенція, що дозволяє закарбувати у собі всю складність світу, а не лише його абстрактний зріз чи зліпок [Кампер 2010: 102].

По-друге, корелят болю відчутно присутній в аналізованому творі тому, що і назва останнього, і непоодинокі відсилки до відповідної релігійної символіки недвозначно свідчать про зв’язок із «християнською вірою, надзвичайно важливу частину якої становить [власне] зустріч із болем» [Хайдарова Боль I].

У зв’язку із цим історикиня мистецтва К. Ван ден Берг ставить питання про те, чому в історії мистецтва наявна величезна кількість образів, які демонструють біль, смерть і вбивство, та що означає той факт, за яким центральним образом християнства стають сцени, що зображають страждання і катування персонажів, починаючи з Ісуса Христа.

Отож основна ідея цієї авторки полягає у тому, що відповідні образи детермінують емоційний відгук, який, своєю чергою, слугує у якості «гальмуючої поверхні», сприяє «самоконституюванню», а також провокує «на творення сенсів». Або, сказати б інакше, за К. Ван ден Берг, «той, хто переживає біль - навіть якщо це відбувається не з його власної волі, починає у специфічний спосіб „розуміти” себе у своєму ставленні до світу, і це розуміння $€$ завжди культурно зумовленим» [Berg 2007: 175]. 
А відтак, по-третє, наведену щойно інтерпретацію, либонь, можна поширити і на того, хто такий біль завдає. Бо містерія неможлива тільки за участі мучеників і тих, хто кричить «Розіпни!»- для повноти картини потрібен ще кат! Який подеколи «вмиває руки», але частіше все ж таки не цурається «брудної роботи».

У цьому сенсі прикметною є на перший погляд не зовсім зрозуміла сцена під час першого вбивства, коли Білозуб, повідрізавши голови хазяїну квартири і двом його найманим робітникам, поскладав їх на журнальному столику і «вичитав лекцію, цілу промову головам».

Щоправда, зміст «лекції» залишився невідомим, але це немає принципового значення остільки, оскільки сенс згаданого епізоду полягає, вочевидь, у пародійному обертанні відомого біблійного сюжету, пов'язаного із відтятою головою Івана Хрестителя заради дочки Іродіади Саломеї, яка аж так невірогідно втішила своїм танцем царя Ірода, що «поклявся він їй: „Чого тільки від мене попросиш, то дам я тобі, хоча б і півцарства мого!”» (Мp. 6: 23).

Цим, власне, «Іродом» і водночас воїном, який відсік голову уявному Івану Предтечі, вочевидь, напівпритомно усвідомлює себе Білозуб, а у сусідці він, певно, вбачає Саломею та Іродіаду в одній особі. Проте згадане пародійне обертання легендарної історії призводить до того, що під «ніжну музику Сен-Санса» танцює не жінка, яку він змушує вдягнути святкову сукню і приготувати йому їжу, - мотив танцю, так само макабрично-пародійно обернений, виникає у зв'язку із «хазяїн[ом] кватири, одягнени[м] у шикарні, майже небесного кольору джинси», бо «його напрацьовані, дужі, як у вантажника, руки, [були] викручені так, наче у танці святого Віта».

У цій же макабрично-оберненій площині можна, либонь, інтерпретувати і маніпуляції Білозуба з тілом самої жінки, адже перед тим, як «він ухопив сокирку для м'яса і одним махом стяв їй голову», «він засунув їй тесака в анус, і з приємністю, з нечуваною насолодою слухав пронизливе, наче осінній вітер, верещання».

Натомість підставу для можливості са́ме такого розуміння становить визначення маніяка у тексті роману i, зокрема, безпосередньо у згадуваному епізоді як такого, що «був людиною вихованою, чемною і культурною».

Відтак, учетверте, цього «культурного» індивідуума на іншому рівні позначено ще «дофіном Сатани» не тому, що Білозуб і справді мав якусь причетність до цілком вигаданого містичного персонажа, а тому, що і для цього протагоніста, і для його автора - це був, певно, єдиний спосіб хоч якось і хоч через якісь культурні процедури, - а інших процедур, придатних для такої мети, властиво, просто не існує! - тепер вже дискурсивно, спираючись на релігійний претекст, легітимізувати в особі образу Івана Білозуба канібальське збочено-криваве підгрунтя, що на ньому постає антропологічна істота, яку зазвичай ще називають людиною.

Отже, аналітика роману Олеся Ульяненка «Дофін Сатани», грунтована на тілесному кореляті болю, дозволила, з одного боку, заперечити суспільно-історичну та містично- 
релігійну інтерпретації, а, з іншого боку, запропонувати вірогідну версію щодо розуміння змісту розглянутого твору, у якому поведінка та вчинки персонажів зумовлюються їхною тілесною здатністю до переживання болісних імпульсів, що не тільки засвідчують емоційноестетичну вірогідність посталих образів, а й визначають їхній аж ніяк не тваринний, а, навпаки, власне антропологічний вимір.

Тож повсякчасне «борсання в морі крові» зумовлено простим і незаперечним фактом, за яким і персонажі, i автор, i, щонайголовніше, читачі, тобто всі ми, є безпосередньо приналежними до означеного виміру, тому що для нас та чи інша причетність до жорстокого світу є, либонь, навіть більш чи принаймні не менш природною, ніж переживання радості або щастя.

\section{ЛІТЕРАТУРА}

Кампер, Д. Тело. Насилие. Боль. Санкт-Петербург, 2010 [Kamper. D. Telo. Nasilie. Bol'. Sankt-Peterburg, 2010].

Пуніна, О. Самітний геній: Олесь Ульяненко: літературний портрет. Київ, 2016 [Punina, O. Samitniy heniy: Oles' Ulyanenko: literaturniy portret. Kiyiv, 2016].

Соловей, О. На боці світла і добра (Декілька слів про Олеся Ульяненка). В: Соловей, О. Оборонні бої: Статті, рецензії, есеї. Донецьк, 2013. 19-31 [Solovey, O. Na botsi svitla I dobra (Dekil'ka sliv pro Olesya Ulyanenka). V: Solovey, O. Oboronni boyi: Statti, retsenziyi, eseyi. Donetsk, 2013. 19-31].

Тендітна, Н. М. Естетика смерті у прозі Є. Пашковського та О. Ульяненка: автореф. ... канд. філол. наук. Кіровоград, 2009. URL: https://revolution.allbest.ru/culture/00592836_0.html (28.09.2020) [Tenditna, N.M. Estetika smerti u prozi Ye.Pashkovs'koho I O.Ulyanenka: avtoref. ... kand. filol. nauk. Kirovohrad, 2009].

Ульяненко, О. Дофін сатани. URL: https://www.rulit.me/books/dofin-satani-read-467240-1.html (17.09.2020) [Ulyanenko, O. Dofin satani].

Хайдарова, Г. MEDIUM боли. URL: http://mediaphilosophy.ru/biblioteca/articles/khaydarova_pain/ (20.09.2020) [Khaydarova, G. MEDIUM boli].

Хайдарова, Г. Боль в культуре. Подходы, концепции, комментарии. Аналитический обзор (Часть I). URL: http://paininfo.ru/articles/4289.html (26.09.2020) [Khaydarova, G. Bol' v kul'ture. Podkhodi, kontseptsii, kommentarii. Analiticheskiy obzor (Chast' I)].

Хайдарова, Г. Боль в культуре. Подходы, концепции, комментарии. Аналитический обзор (Часть II). URL: http://paininfo.ru/articles/4292.html (27.09.2020) [Khaydarova, G. Bol' v kul'ture. Podkhodi, kontseptsii, kommentarii. Analiticheskiy obzor (Chast' II)].

Хайдарова Г. Боль в культуре. Подходы, концепции, комментарии. Аналитический обзор (Часть III). URL: http://paininfo.ru/articles/4293.html (23.09.2020) [Khaydarova, G. Bol' v kul'ture. Podkhodi, kontseptsii, kommentarii. Analiticheskiy obzor (Chast' III)].

Хайдарова, Г. Р. Феномен боли: дис. ... канд. филос. наук. Санкт-Петербург, 2003 [Khaydarova, G. Fenomen boli: diss. ... kand. filos. nauk. Sankt-Peterburg, 2003].

Хайдарова Г. Феномен боли в европейской культуре. URL: http://www.paininfo.ru/articles/2499.html (23.09.2020) [Khaydarova, G. Fenomen boli v yevropeyskoy kul'ture].

Штейнбук, Ф. Конвергенція тілесних мікротопосів у сучасній світовій літературі. Київ, 2014 [Shteynbuk, F. Konvergentsiya tilesnikh mikrotoposiv u suchasniy svitoviy literature. Kiyiv, 2014].

Berg, K. Van den. Der Schmerz des Anderen. Berlin 2007.

Horniatko-Szumiłowicz, А. Чуттєве сприйняття романів Олеся Ульяненка. «Slavica Wratislaviensia». 2015. № CLXI. 189-199. 